\title{
UPAYA MENINGKATKAN DISIPLIN GURU DALAM KEHADIRAN MENGAJAR DI KELAS MELALUI PENERAPAN REWARD AND PUNISHMENT DI SMA SWASTA MANARUL ISLAM KABUPATEN ACEH TAMIANG
}

\author{
Ahmad Syafwan \\ Sekolah Menengah Atas Swasta Manarul Islam \\ syafwanahmad@gmail.com
}

\begin{abstract}
Abstrak: Tujuan Penelitian ini adalah upaya meningkatkan disiplin guru dalam kehadiran mengajar di kelas melalui penerapan reward and punishment di SMA Swasta Manarul Islam Kabupaten Aceh Tamiang, sebagai upaya peningkatan mutu pembelajaran di sekolah. Beberapa faktor penting dalam peningkatan mutu tersebut di antaranya adalah penerapan budaya sekolah yang positif dan berkesinambungan. Budaya sekolah yang positif tentunya harus dipertahankan dan dilaksanakan oleh semua warga sekolah tanpa terkecuali dan tidak merasa terpaksa. Dalam menerapkan budaya sekolah perlu sikap kesadaran dari semиa warga sekolah secara bersama-sama. Salah satu budaya sekolah yang harus dipertahankan adalah kedisiplinan, kedisiplinan guru dalam kehadiran di kelas pada proses belajar mengajar. Untuk meningkatkan disiplin para guru dapat diupayakan melalui bermacam-macam cara. Dalam Penelitian Tindakan Sekolah (PTS) ini, dicobakan tindakan berupa penerapan Reward and Punishment bagi para guru di SMA Swasta Manarul Islam, Kabupaten Aceh Tamiang. Penelitian ini dilaksanakan dalam dua siklus, karena dari hasil penelitian dan analisa data, ternyata pada siklus kedua, kedisiplinan guru, dalam kehadiran di kelas pada proses belajar mengajar meningkat dan memenuhi indikator yang telah ditetapkan sebesar 80\%. Dari hasil penelitian ini, dapat disimpulkan bahwa untuk meningkatkan disiplin guru dalam kehadiran di kelas pada kegiatan belajar mengajar dapat dilakukan dengan penerapan Reward and Punishment kepada guru.
\end{abstract}

Kata Kunci: Disiplin Guru, Reward and Punishment.

Abstract: The objective of this study was to improve teacher's discipline in teaching attendance in class through the application of reward and punishment at the Manarul Islam Private High School, Aceh Tamiang Regency, as an effort to improve the quality of learning in school. Some important factors in improving the quality was the implementation of a positive and sustainable school's culture. A positive school's culture must be maintained and implemented by all school members without exception and do not feel forced. In implementing school's culture, it is necessary to have an attitude of awareness from all school members. One of the school's cultures that must be maintained is discipline that was teachers' discipline in class attendance in the teaching and learning process. To improve the discipline of teachers, it can be acted in various ways. In this School Action Research, tried to study by applying Reward and Punishment for teachers at Manarul Islam Private High School, Aceh Tamiang Regency. This research was conducted in two cycles, the results of research and data analysis, it turned out in the second cycle, teacher's discipline, in class attendance in the teaching and learning process increased and met the predetermined indicators of $80 \%$. From the results of this study, it can be concluded that to improve teacher's discipline in class attendance in teaching and learning activities can be done by applying Reward and Punishment to teachers.

Keywords: Teacher Discipline, Reward and Punishment.

\section{PENDAHULUAN}

Memiliki mutu dan kualitas pendidikan merupakan cita-cita setiap Bangsa maupun Negera diseluruh pelosok dunia. Indonesia merupakan negara berkembang yang terus menerus berupaya melakukan perbaikan terhadap sistem pendidikannya, adanya perubahan-perubahan kurikulum disetiap pergantian menteri pendidikan menunjukkan contoh bahwa upaya pemerintah Indonesia terus berupaya membenahi sistem pendidikannya.

Upaya menjadikan pendidikan yang lebih baik tidak terlepas dari bagaimana memajukan kesejahateraan masyarakat Indonesia agar terlepas dari ketertinggalan dan tidak tergantung pada negara-negara lainnya, masyarakat dipersiapkan untuk mampu mengikuti era perkembangan zaman.

Namun demikian dalam upaya untuk meningkatkan kesejahteraan dan mencerdaskan kehidupan bangsa, pendidikan juga berperan penting dalam meningkatkan ketakwaan kepada Tuhan Yang Maha Esa. Dengan harapan terciptanya masyarakat yang berpengetahuan, memiliki keterampilan, berakhlak mulia dengan 
tidak melupakan kodratnya sebagai makhluk ciptaan Allah SWT.

Satuan Pendidikan sebagai salah satu ujung tombak yang berperan penting dalam memajukan pendidikan di tanah air, satuan pendidikan merupakan tempat dimana kegiatan dan proses belajar mengajar berlangsung menentukan peserta didik apakah dapat melanjutkan ke jenjang berikutnya atau tidak. Maka satuan pendidikan sudah seharusnya memiliki perencanaan program kegiatan yang mampu berdayasaing memberikan solusi terhadap berbagai permasalahan pendidikan.

Satuan pendidikan juga harus mampu memberikan layanan terbaiknya kepada peserta didik sebagai penunjang terlaksanya proses pembelajaran yang bermutu dan berkualitas. Tidak jarang banyak satuan pendidikan yang mutunya rendah disebabkan dalam memberikan layanan kepada peserta didik kurang maksimal. Dari banyak faktor penyebab menurunnya mutu pendidikan di satuan pendidikan antara lain, 1) Kurang lengkapnya sarana dan prasarana belajar, 2) Sumber daya manusia yang rendah, 3) rendahnya kesadaran dalam menjalankan tugas dengan baik, 4) banyak guru tidak mendapatkan pelatihan.

Dari beberapa faktor penyebab rendahnya mutu satuan pendidikan penulis berkesimpulan rendahnya kesadaran dalam menjalankan tugas dengan baik merupakan faktor utama yang harus diperbaiki, dengan alasan di tangan gurulah terletak kemungkinan berhasil atau tidaknya pencapaian tujuan belajar mengajar di sekolah. Oleh karena tugas dan peran guru bukan saja mendidik, mengajar dan melatih tetapi guru juga dituntut dapat membaca situasi kelas dan menguasai kelas serta memahami karakteristik siswanya dalam proses pembelajaran.

Sebagai upaya meningkatkan peran guru dalam proses belajar mengajar dan hasil belajar siswa, maka guru diharapkan mampu menciptakan lingkungan belajar yang efektif dan efesien dalam mengelola kelas. Guru adalah pendidik profesional dengan tugas utama mendidik dan mengevaluasi peserta didik, pada semua jenjang pendidikan. Sementara pegawai dunia pendidikan merupakan bagian dari tenaga kependidikan, yaitu anggota masyarakat yang mengabdikan diri dan diangkat sebagai penunjang penyelenggaraan pendidikan. Dalam informasi tentang wawasan Wiyatamandala, kedisiplinan guru diartikan sebagai sikap mental yang mengandung kerelaan mematuhi semua ketentuan, peraturan dan norma yang berlaku dalam menunaikan tugas dan tangung jawabnya. Dari penjelasan diatas dapat disimpulkan, kedisiplinan guru dan pegawai adalah sikap penuh kerelaan dalam mematuhi semua aturan dan norma yang ada dalam menjalankan tugasnya sebagai bentuk tanggung jawabnya terhadap pendidikan peserta didiknya. Karena bagaimana pun seorang guru atau tenaga kependidikan (pegawai), merupakan cermin bagi peserta didiknya dalam sikap atau teladan, dan sikap disiplin guru dan tenaga kependidikan (pegawai) akan memberikan warna terhadap hasil pendidikan yang jauh lebih baik.

Keberhasilan pembelajaran sangat bergantung pada beberapa faktor di antaranya adalah faktor guru. Pentingnya peran guru sangat menentukan dalam keberhasilan proses pembelajaran. Guru yang mempunyai kompetensi yang baik tentunya akan sangat mendukung keberhasilan proses pembelajaran.

Peranan guru selain sebagai seorang pengajar, guru juga berperan sebagai seorang pendidik. Pendidik adalah setiap orang yang dengan sengaja mempengaruhi orang lain untuk mencapai tingkat kemanusiaan yang lebih tinggi (Sutari Imam Barnado, 1989:44). Sehinggga sebagai pendidik, seorang guru harus memiliki kesadaran atau merasa mempunyai tugas dan kewajiban untuk mendidik. Tugas mendidik adalah tugas yang amat mulia atas dasar "panggilan" yang teramat suci. Sebagai komponen sentral dalam sistem pendidikan, pendidik mempunyai peran utama dalam membangun fondamen-fondamen hari depan corak kemanusiaan.

Permasalahan kurang disiplinnya guru masuk kedalam kelas pada saat kegiatan pembelajaran merupakan Fakta lapangan yang sering di jumpai di setiap sekolah.

Berdasarkan uraian, fakta dan pengalaman penulis, penulis tertarik untuk melakukan penelitian tindakan sekolah dengan judul: "Upaya Meningkatkan Disiplin Guru dalam Kehadiran Mengajar Di kelas Melalui penerapan Reward and Punishment di SMA Swasta Manarul Islam, Kabupaten Aceh Tamiang."

\section{METODE}

Prosedur penelitian tindakan ini dilaksanakan dengan metode Penelitian Tindakan Sekolah (PTS). PTS merupakan suatu prosedur penelitian yang diadaptasi dari Penelitian Tindakan Kelas (PTK) (Panitia Pelaksana Pendidikan dan Latihan Profesi Guru 
Rayon 10 Jawa Barat, 2009:73). Penelitian tindakan sekolah merupakan "(1) penelitian partisipatoris yang menekankan pada tindakan dan refleksi berdasarkan pertimbangan rasional dan logis untuk melakukan perbaikan terhadap suatu kondisi nyata; (2) memperdalam pemahaman terhadap tindakan yang dilakukan; dan (3) memperbaiki situasi dan kondisi sekolah/pembelajaran secara praktis" (Depdiknas, 2008:11-12). Secara singkat, PTS bertujuan untuk mencari pemecahan permasalahan nyata yang terjadi di sekolahsekolah, sekaligus mencari jawaban ilmiah bagaimana masalah-masalah tersebut bisa dipecahkan melalui suatu tindakan perbaikan.

Pendekatan yang digunakan dalam penelitian tindakan ini ialah pendekatan kualitatif. Artinya, penelitian ini dilakukan karena ditemukan permasalahan rendahnya tingkat kedisiplinan guru dalam kehadiran di kelas pada proses kegiatan belajar mengajar. Permasalahan ini ditindaklanjuti dengan cara menerapkan sebuah model pembinaan kepada guru berupa penerapan Reward dan Punishment yang dilakukan oleh kepala sekolah, kegiatan tersebut diamati kemudian dianalisis dan direfleksi. Hasil revisi kemudian diterapkan kembali pada siklus-siklus berikutnya.

Penelitian ini adalah penelitian tindakan model Stephen Kemmis dan Mc. Taggart (1998) yang diadopsi oleh Zainal Aqib (2006:49) yang kemudian diadaptasikan dalam penelitian ini. Model ini menggunakan sistem spiral refleksi diri yang dimulai dari rencana, tindakan, pengamatan, refleksi, dan perencanaan kembali yang merupakan dasar untuk suatu ancangancang pemecahan masalah.

Kegiatan penelitian tindakan sekolah ini, terdiri atas beberapa tahap, yaitu: (1) Perencanaan, (2) Pelaksanaan, (3) Pengamatan dan (4) Refleksi.

Teknik pengumpulan data penelitian tindakan sekolah ini adalah melalui metode data kualitatif yang diperoleh dari wawancara, data sekolah dan observasi atau pengamatan.

Analisa data yang digunakan dalam penelitian ini adalah analisa data kualitatif yang bersumber dari data primer maupun empiris. Melalui analisa data ini, dapat diketahui ada tidaknya peningkatan kedisiplinan guru dalam kehadiran di kelas melalui pemberian reward dan punishment yang merupakan fokus dari penelitian tindakan sekolah ini.

Indikator keberhasilan dari penelitian tindakan sekolah ini adalah: (1) Indikator yang menunjukkan membudayanya prilaku disiplin guru hadir di di kelas sebesar $80 \%$. (2) Indikator yang diperoleh dari data terpenuhinya kehadiran guru yang diperoleh dari data absensi elektronik (figer print) dan (3) Indikator yang diperoleh dari data terpenuhinya kehadiran guru yang diperoleh dari jurnal kelas ketika melaksanakan aktifitas belajar mengajar.

\section{HASIL}

\section{Siklus I}

Siklus I ini terdiri atas beberapa tahap, Agar perencanaan mudah dipahami dan dilaksanakan maka penulis membuat rencana tindakan (a) Merumuskan masalah yang akan dicari solusinya. Dalam penelitian ini masalah yang akan dicari solusinya adalah masih banyaknya guru yang kurang disiplin dalam masalah kehadiran di kelas pada proses belajar mengajar. (b) Merumuskan tujuan penyelesaian masalah/tujuan menghadapi tantangan/tujuan melakukan inovasi/tindakan. Dalam penelitian ini penulis mengambil rencana untuk melakukan tindakan memberikan Reward dan Punishment kepada guru-guru untuk meningkatkan kedisiplinan guru dalam kehadiran di kelas pada proses belajar mengajar. (c) Merumuskan indikator keberhasilan penerapan Reward dan Punishment dalam meningkatkan disiplin guru dalam kehadiran di kelas pada proses belajar mengajar. Indikator keberhasilan penerapan tindakan ini penulis tetapkan sebesar $80 \%$, artinya tindakan ini dinyatakan berhasil bila $80 \%$ guru tidak terlambat masuk kelas dalam proses pembelajaran. (d) Merumuskan langkah-langkah kegiatan penyelesaian masalah/kegiatan menghadapi tantangan/kegiatan melakukan tindakan.

Langkah-langkah yang diambil penulis dalam melakukan tindakan antara lain adalah melakukan sosialisasi kepada para guru mengenai penelitian yang akan dilaksanakan, serta menyampaikan tujuan dari penerapan tindakan yang dilakukan oleh penulis.

Kepada para guru disampaikan mengenai penerapan Reward dan Punishment yang akan diterapkan dalam penelitian ini. Pada siklus pertama ini, akan disampaikan melalui group WhatsApp sekolah, dan pada rapat rutin sekolah, peringkat nama-nama guru yang paling rendah tingkat keterlambatan masuk kelasnya sampai yang paling tinggi tingkat keterlambatannya. (e) Mengidentifikasi warga sekolah dan atau pihak-pihak terkait lainnya yang terlibat dalam penyelesaian 
masalah/menghadapi tantangan/melakukan tindakan. Penulis melakukan identifikasi siapa saja yang dilibatkan dalam penelitian ini. Pihakpihak yang dilibatkan dalam penelitian ini adalah : guru, guru piket, TU, dan siswa. (f) Mengidentifikasi metode pengumpulan data yang akan digunakan.

Metode pengumpulan data yang diambil oleh penulis merupakan data kualitatif melalui observasi, pengamatan serta wawancara kepada siswa mengenai kehadiran guru di kelas pada kegiatan belajar mengajar. (g) Penyusunan instrumen pengamatan dan evaluasi.

Dalam pengambilan data, penulis menggunakan instrument berupa lembar observasi/pengamatan, skala penilaian serta angket yang disebarkan kepada siswa, untuk mengetahui penilaian dari siswa mengenai tingkat kehadiran guru di kelas dalam proses kegiatan belajar mengajar. (h) Mengidentifikasi fasilitas yang diperlukan.

Fasilitas atau alat bantu yang digunakan dalam penelitian ini antara lain: kertas (lembar pengamatan), alat tulis berupa balpoin, figer print serta jam dinding yang ada di kantor dan disetiap kelas, serta rekap jumlah kehadiran dari setiap guru.

Pelaksanaan penelitian tindakan sekolah ini dilaksanakan melalui beberapa kegiatan, antara lain: (a) Menyebarkan lembar pengamatan kepada setiap Ketua Kelas atau Sekretaris kelas sebanyak 6 set, sesuai dengan banyaknya jumlah rombongan belajar di SMA Swasta Manarul Islam sebanyak 6 rombongan belajar. Dalam lembar pengamatan itu, telah dibuat daftar guru yang mengajar di kelas itu setiap jam dan diberi kolom jam masuk kelas serta jam keluar kelas. Lembar pengamatan dapat dilihat pada lampiran. (b) Berkoordinasi dengan petugas piket yang setiap hari terdiri dari 2 orang petugas, yaitu dari guru yang tidak mempunyai jam mengajar pada hari itu dan satu orang dari tata usaha. Petugas piket akan mengedarkan daftar hadir guru di kelas yang telah dibuat agar dapat melihat tingkat kehadiran guru disetiap kelas dan disetiap pergantian jam pelajaran. Guru yang terlambat lebih dari 15 menit, dianggap tidak hadir dan diberi tanda silang. Daftar hadir guru dapat dilihat dalam lampiran. (c) Setelah selesai jam pelajaran, dilakukan rekapitulasi dari hasil pengamatan, baik dari guru piket, dari siswa maupun dari penulis. (d) Kegiatan tersebut dilakukan terus setiap hari kepada setiap guru selama satu minggu (satu siklus).
Pengamatan atau observasi dilakukan oleh peneliti dengan menggunakan lembar observasi selama satu minggu (satu siklus), untuk semua guru yang berjumlah 16 orang. Selama pengamatan peneliti dibantu atau berkolaborasi dengan guru piket. Pengamatan oleh peneliti meliputi: (a) Kehadiran guru di kelas, (b) Tingkat keterlambatan guru masuk kelas, (c) Waktu meninggalkan kelas setelah selesai pelajaran

Peneliti juga melakukan penilaian dari hasil lembar observasi yang dibagikan kepada pengurus kelas untuk mengamati kehadiran guru di kelas.

Dari hasil pengamatan serta rekap dari tingkat kehadiran guru di kelas pada proses belajar mengajar dapat dilihat pada tabel berikut:

Tabel 1. Rekapitulasi Tingkat Keterlambatan Guru Pada Kehadiran di Kelas Siklus I

Waktu Keterlambatan/Jumlah/Prosentase

\begin{tabular}{c|c|c}
\hline$<10$ Menit & 10 s.d. 15 Menit & $>15$ Menit \\
\hline 9 & 3 & 4 \\
\hline $56,25 \%$ & $18,75 \%$ & $25 \%$ \\
\hline
\end{tabular}

Dari hasil rekapitulasi tingkat keterlambatan guru di kelas pada proses pembelajaran diperoleh data, sebanyak 9 orang guru terlambat masuk kelas kurang dari 10 menit, 3 orang guru terlambat masuk kelas 10 menit sampai dengan 15 menit, dan 4 orang guru terlambat masuk kelas lebih dari 15 menit. Untuk lebih jelasnya dapat digambarkan pada grafik dibawah ini:

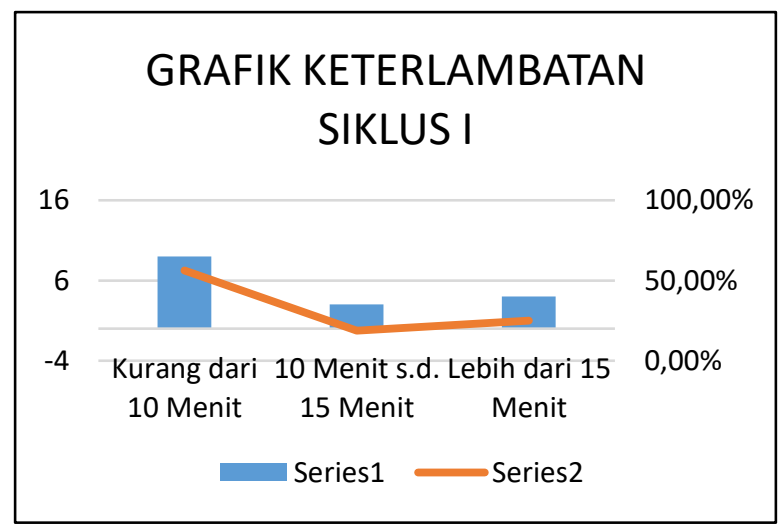

Gambar 2. Grafik Keterlambatan guru siklus I

Dari data diatas dapat ditarik kesimpulan bahwa tingkat keterlambatan guru masuk kelas lebih dari 15 menit pada proses kegiatan belajar mengajar masih tinggi yaitu 2 orang atau $25 \%$. Berdasarkan indicator yang 
telah ditetapkan bahwa keberhasilan tindakan ini adalah $80 \%$, atau bila $80 \%$ guru tidak terlambat lebih dari 10 menit. Pada siklus pertama ini guru yang tidak terlambat lebih dari 10 menit baru $56,25 \%$, jadi peneliti berkesimpulan harus diadakan penelitian atau tindakan lagi pada siklus berikutnya atau siklus kedua.

Refleksi dilaksanakan bersama-sama kolaborator untuk menentukan tindakan perbaikan pada siklus berikutnya.

Dari hasil refleksi dapat diambil suatu kesimpulan bahwa perlu penerapan Reward dan Punishment yang lebih tegas lagi daripada siklus pertama.

\section{Siklus II}

Siklus II terdiri atas beberapa tahap, sama seperti siklus I yaitu: (1) Perencanaan, (2) Pelaksanaan, (3) Pengamatan dan Evaluasi, dan (4) Refleksi.

Dari hasil refleksi pada siklus pertama, peneliti merencanakan untuk melakukan tindakan Reward dan Punishment yang lebih tegas dibandingkan dengan siklus pertama.

Peneliti merencanakan mengumumkan hasil observasi mengenai tingkat keterlambatan guru masuk kelas dalam proses belajar mengajar, pada kegiatan rapat rutin di sekolah. Hal ini terlebih dahulu disosialisasikan kepada semua guru pada saat refleksi siklus pertama.

Pelaksanaan penelitian tindakan sekolah pada siklus yang kedua ini dilaksanakan melalui beberapa kegiatan, antara lain: (a) Menyebarkan lembar pengamatan kepada setiap Ketua Kelas atau Sekretaris kelas sebanyak 6 set, sesuai dengan banyaknya jumlah rombongan belajar di SMA Swasta Manarul Islam sebanyak 6 rombongan belajar. Dalam lembar pengamatan itu, telah dibuat daftar guru yang mengajar di kelas itu setiap jam dan diberi kolom jam masuk kelas serta jam keluar kelas. Lembar pengamatan dapat dilihat pada lampiran, (b) Berkoordinasi dengan petugas piket yang setiap hari terdiri dari 2 orang petugas, yaitu dari guru yang tidak mempunyai jam mengajar pada hari itu dan satu orang dari tata usaha. Petugas piket akan mengedarkan daftar hadir guru di kelas yang telah dibuat agar dapat melihat tingkat kehadiran guru disetiap kelas dan disetiap pergantian jam pelajaran. Guru yang terlambat lebih dari 15 menit, dianggap tidak hadir dan diberi tanda silang. Daftar hadir guru dapat dilihat dalam lampiran, (b) Setelah selesai jam pelajaran, dilakukan rekapitulasi dari hasil pengamatan, baik dari guru piket, dari siswa maupun dari penulis, (c) Kegiatan tersebut dilakukan terus setiap hari kepada setiap guru selama satu minggu (satu siklus) pada siklus kedua

Pengamatan atau observasi dilakukan oleh peneliti dengan menggunakan lembar observasi selama satu minggu (satu siklus), untuk semua guru yang berjumlah 16 orang. Selama pengamatan peneliti dibantu atau berkolaborasi dengan guru piket. Pengamatan oleh peneliti meliputi: (a) Kehadiran guru di kelas, (b) Tingkat keterlambatan guru masuk kelas, (c) Waktu meninggalkan kelas setelah selesai pelajaran.

Peneliti juga melakukan penilaian dari hasil lembar observasi yang dibagikan kepada pengurus kelas untuk mengamati kehadiran guru di kelas.

Dari hasil pengamatan serta rekap dari tingkat kehadiran guru di kelas pada proses belajar mengajar pada siklus kedua dapat dilihat pada tabel berikut:

Tabel 2. Rekapitulasi Tingkat Keterlambatan Guru Pada Kehadiran di Kelas Siklus II

Waktu Keterlambatan/Jumlah/Prosentase

\begin{tabular}{c|c|c}
\hline$<10$ Menit & 10 s.d. 15 Menit & $>15$ Menit \\
\hline 14 & 2 & 0 \\
\hline $87,50 \%$ & $12,50 \%$ & $0,00 \%$ \\
\hline
\end{tabular}

Dari hasil rekapitulasi tingkat keterlambatan guru di kelas pada proses pembelajaran diperoleh data, sebanyak 14 orang guru terlambat masuk kelas kurang dari 10 menit, 2 orang guru terlambat masuk kelas 10 menit sampai dengan 15 menit, dan tidak ada satu orangpun guru yang terlambat masuk kelas lebih dari 15 menit.

Untuk lebih jelasnya, tingkat keterlambatan guru masuk kelas pada proses belajar mengajar pada siklus kedua ini dapat digambarkan pada grafik dibawah ini:

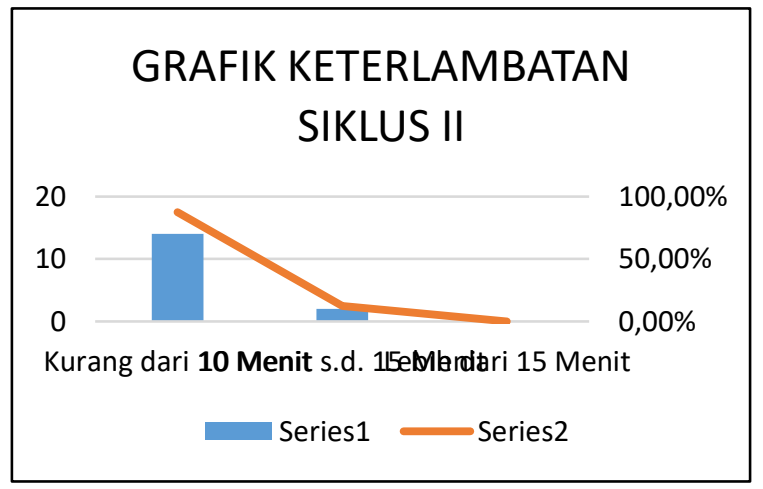

Gambar 3. Grafik Keterlambatan guru siklus II 
Dari hasil observasi pada siklus pertama dan siklus kedua dapat dilihat ada penurunan tingkat keterlambatan guru di kelas pada kegiatan belajar mengajar, atau terdapat peningkatan kehadiran guru di kelas.

Setelah selesai pelaksanaan tindakan pada siklus kedua maka diadakan refleksi mengenai kelemahan atau kekurangan dari pelaksanaan tindakan pada siklus kedua tersebut, peneliti mengambil kesimpulan bahwa tindakan yang dilaksanakan pada siklus kedua dinyatakan berhasil, karena terdapat $87,50 \% \%$ guru yang terlambat kurang dari 10 menit, atau melebihi target yang telah ditentukan sebesar $80 \%$.

\section{PEMBAHASAN}

Pembahasan hasil penelitian tindakan sekolah ini, dimana menerapkan reward dan punishment sebagai upaya meningkatkan kedisiplinan guru dalam kehadiran di kelas pada proses belajar mengajar di SMA Swasta Manarul Islam Kecamatan Kejuruan Muda Kabupaten Aceh Tamiang, Provinsi Aceh, terangkum dalam siklus I dan siklus II, menunjukkan hasil yang signifikan.

Pendekatan yang digunakan dalam penelitian tindakan ini ialah pendekatan kualitatif. Artinya, penelitian ini dilakukan karena ditemukan permasalahan rendahnya tingkat kedisiplinan guru dalam kehadiran dikelas pada proses kegiatan belajar mengajar di SMA Swasta Manarul Islam Kabupaten Aceh Tamiang. Selanjutnya permasalahan ini ditindaklanjuti dengan menerapkan sebuah model pembinaan kepada guru-guru berupa penerapan reward dan punishment yang dilakukan oleh kepala sekolah, kegiatan tersebut diamati kemudian dianalisis dan direfleksi. Hasil revisi kemudian diterapkan kembali pada siklussiklus berikutnya. Penelitian ini diadaptasikan dengan penelitian tindakan model Stephen Kemmis dan Mc. Taggart (1998) yang diadopsi oleh Suranto (2000:49). Model ini menggunakan sistem spiral refleksi diri yang dimulai dari rencana, tindakan, pengamatan, refleksi, dan perencanaan kembali yang merupakan dasar untuk suatu persiapan pemecahan masalah.

Penelitian Tindakan Sekolah (PTS) ini dilaksanakan dalam dua siklus. Dikarenakan keterbatasan waktu yang tersedia dan penyesuaian terhadap kalender akademik di sekolah, lagipula dengan dua siklus penulis menganggap sudah cukup untuk peningkatan disiplin guru dalam kehadiran di kelas pada kegiatan belajar mengajar. Indikator keberhasilan penerapan tindakan ini penulis tetapkan sebesar $80 \%$, artinya tindakan ini dinyatakan berhasil bila $80 \%$ guru tidak terlambat masuk kelas dalam proses pembelajaran. Langkah-langkah yang diambil penulis dalam melakukan tindakan antara lain adalah melakukan sosialisasi kepada para guru mengenai penelitian yang akan dilaksanakan, serta menyampaikan tujuan dari penerapan tindakan yang dilakukan oleh penulis. Kepada para guru disampaikan mengenai penerapan Reward dan Punishment yang akan diterapkan dalam penelitian ini. Pada siklus pertama ini, dishare melalui media group WhatsApp sekolah, yakni peringkat nama-nama guru yang sering terlambat masuk ke kelasnya.

\section{Pelaksanaan penelitian}

tindakan sekolah ini dilaksanakan melalui beberapa kegiatan, yaitu: (a) Menyebarkan lembar pengamatan kepada setiap Ketua Kelas atau Sekretaris kelas sebanyak 6 kelas, sesuai jumlah rombongan belajar di SMA Swasta Manarul Islam Kabupaten Aceh Tamiang. Dalam lembar pengamatan telah dibuat daftar nama guru yang mengajar di kelas sesuai jadwal mata pelajaran dan diberi kolom jam masuk ke kelas serta jam keluar dari kelas. (b) Peneliti berkoordinasi dengan petugas/guru piket yang setiap hari terdiri dari 2 orang petugas, yaitu dari guru yang tidak mempunyai jam mengajar pada hari itu. Petugas piket mengamati dan mencatat kehadiran guru di kelas dan disetiap pergantian jam pelajaran. Guru yang terlambat lebih dari 15 menit, dianggap tidak hadir dan diberi tanda silang. (c) Setelah selesai jam pelajaran, dilakukan rekapitulasi dari hasil pengamatan, baik dari guru piket, dari siswa maupun dari penulis yang selanjutnya disampaikan ke penulis dan dijadikan sebagai data/informasi bagi penulis. (d) Sedangkan untuk tingkat kehadiran guru dan TU di sekolah, penulis bekerjasama dengan wakil bidang kurikulum dan kesiswaan untuk mengamati tingkat kedisiplinan guru hadir di sekolah, dengan memberikan informasi langsung melalui WhatsApp group waka lengkap dengan jam kehadiran. (e) Kegiatan tersebut dilakukan terus setiap hari kepada setiap guru selama satu minggu (satu siklus).

Dari hasil observasi yang dilakukan penulis selama satu siklus data yang diperoleh menunjukkan pada siklus I sebagian besar guru 
dalam melaksanakan kedisiplinan, yang hadir kurang dari 10 menit diperoleh data sebesar $56,25 \%$, dan yang terlambat hadir diantara 10 sampai 15 menit sebesar $18,75 \%$, sedangkan guru yang terlambat hadir melebihi 15 menit sebesar $25 \%$.

Tabel 1. Rekapitulasi Tingkat Keterlambatan Guru Pada Kehadiran di Kelas Siklus I

\begin{tabular}{c|c|c}
\hline \multicolumn{3}{|c}{ Waktu Keterlambatan/Jumlah/Prosentase } \\
\hline$<10$ Menit & 10 s.d. 15 Menit & $>15$ Menit \\
\hline 9 & 3 & 4 \\
\hline $56,25 \%$ & $18,75 \%$ & $25 \%$ \\
\hline
\end{tabular}

Berdasarkan data pada siklus I, maka perlu dilakukan evaluasi terhadap kelemahankelemahan yang perlu diperbaiki dan kembali direncanakan untuk selanjutnya dilaksanakan tindakan siklus II.

Berdasarkan hasil refleksi data pada siklus I maka peneliti melakukan pengamatan pada siklus II dengan tindakan yang sama pada siklus I, namun telah dilakukan penyampaian data rekapan temuan selama siklus I terkait tingkat kedisiplinan guru kepada para guru melalui rapat rutin dan menjadi pertimbangan untuk perbaikan pada siklus II dan seterusnya.

Kepada guru yang mengalami kemajuan disiplin diberikan reward; (a) Pujian, pujian diberikan sebagai bentuk penghargaan atas usaha yang dilakukan guru untuk masuk ke kelas tepat waktu. (b) Hadiah, hadiah diberikan dalam bentuk pemberian tambahan penghasilan bagi guru yang bertugas sesuai waktu kehadirannya di kelas. (c) Nilai, nilai kinerja yang baik diberikan kepada guru yang melaksanakan tugas secara disiplin dan tepat waktu. (d) Keaktifan, keaktifan diberikan kepada guru yang disiplin dan tepat waktu bertugas dalam bentuk penerbitan surat aktif sebagai syarat mendapatkan gaji yang bersumber dari pemerintah daerah.

Sebaliknya kepada guru yang tidak menjalankan tugas sesuai waktunya maka akan diberikan Punishment.

Selanjutnya dari hasil data yang diperoleh berdasarkan observasi dilapangan pada siklus II sebagian besar guru sudah jauh lebih baik dalam melaksanakan kedisiplinan, dimana guru yang hadir kurang dari 10 menit diperoleh data sebesar 87,50\%, dan yang terlambat hadir diantara 10 sampai 15 menit sebesar $12,50 \%$, sedangkan guru yang terlambat hadir melebihi 15 menit sebesar $0 \%$.

Tabel 2. Rekapitulasi Tingkat Keterlambatan Guru Pada Kehadiran di Kelas Siklus II

Waktu Keterlambatan/Jumlah/Prosentase

\begin{tabular}{c|c|c}
\hline$<10$ Menit & 10 s.d. 15 Menit & $>15$ Menit \\
\hline 14 & 2 & 0 \\
\hline $87,50 \%$ & $12,50 \%$ & $0,00 \%$ \\
\hline
\end{tabular}

Maka dapat disimpulkan dalam pembahasan penelitian ini, bahwa penerapan reward dan punishment sebagai upaya meningkatkan kedisiplinan guru dalam kehadiran di kelas, diperoleh keberhasil 87,50\% jauh lebih besar dari indikator yang penulis harapkan dalam penelitian ini yakni $80 \%$. Maka Upaya meningkatkan disiplin guru dalam kehadiran mengajar di kelas melalui penerapan reward and punishment di SMA Swasta Manarul Islam Kabupaten Aceh Tamiang dapat di rekomendasikan.

\section{PENUTUP \\ Kesimpulan}

Berdasarkan analisis data, dari penelitian ini dapat ditarik kesimpulan bahwa penerapan Reward dan Punishment efektif untuk meningkatkan disiplin kehadiran guru di kelas pada kegiatan belajar mengajar di SMA Swasta Manarul Islam Kabupaten Aceh Tamiang dapat di rekomendasikan untuk diterapkan sebagai strategi memperbaiki kedisiplinan guru.

Data yang diperoleh menunjukan bahwa setelah diadakan penerapan tindakan berupa Reward dan Punishment, guru yang terlambat lebih dari 15 menit adalah 0 , dan guru yang terlambat kurang dari 10 menit sebanyak 14 orang guru atau $87,50 \%$. Penerapan reward dan punishment dapat meningkat disiplin guru hadir di dalam kelas pada kegiatan belajar mengajar di SMA Swasta Manarul Islam.

\section{Saran}

Karena adanya pengaruh positif Penerapan Reward dan Punishment terhadap disiplin guru hadir di dalam kelas pada kegiatan belajar mengajar, maka melalui kesempatan ini penulis mengajukan beberapa saran:

Selayaknya semua kepala sekolah disarankan melakukan Penerapan reward dan punishment untuk meningkatkan disiplin guru hadir di dalam kelas pada kegiatan belajar mengajar di sekolah. 
Kepada semua guru dalam melaksanakan tugas untuk dapat meningkatkan disiplin dalam kehadiran di kelas sebagai bentuk pelayanan minimal kepada peserta didik di sekolah.

\section{DAFTAR PUSTAKA}

Anwar Prabu Mangkunegara, 2000, Manajemen Sumber Daya Manusia, Bandung. PT, Remaja Rosdakarya.

Akhmad Sudrajat, (2010) Manfaat Prinsip dan Asas Pengembangan Budaya Sekolah. [On Line]. Tersedia: http://akhmadsudrajat.wordpress.com /2010/03/04/manfaat-prinsip-dan-asaspengembangan-budaya-sekolah/ [06 Oktober 2010]

Alex S Nitisemito. 1986. Manajemen Personalia. Jakarta: Ghalia Indonesia.

Anwar Prabu Mangkunegara. (1994). Psikologi Perusahaan. Bandung: PT. Trigenda Karya

Aqib, Zainal. 2006. Penelitian Tindakan Kelas. Bandung: Yrama Widya. (2000). Manajemen Sumber Daya Manusia Perusahaan. Bandung: Penerbit Remaja Rosdakarya.

Arikunto, S. (2002). Prosedur Penelitian Suatu Pendekatan Praktek. Jakarta: Rineka Cipta

Bambang Nugroho. (2006). Reward dan Punishment. Bulletin CiptaKarya Departemen Pekerjaan Umum Edisi No. 6/IV/Juni 2006

Budiningsih, Asri. (2005). Belajar dan Pembelajaran. Jakarta: Rineka Cipta.

Davis, Gordon B, (2002) Sistem Informasi Manajemen, PPM, Jakarta.

Davis, Stephen. Et.al (2005) School Leadership Study, Developing Successful Principal, the Wallace foundation, Standford Educational Leadership Institute, www.srnlead.org. (6 November 2009)

Departemen Pendidikan Nasional. (2003). Undang-undang Nomor 20 Tahun 2003 Tentang Sistem Pendidikan Nasional. Jakarta:Depdiknas

Greenberg \& Baron. (1993). Behavior in Organizations (Fourth Edition). Boston: Allyn and Bacon

Handoko, T. Hani. (2001). Manajemen Personalia dan Sumber Daya Manusia. Yogjakarta.
Hasibuan Malayu S.P. (1997). Manajemen Sumber Daya Manusia. Jakarta: Gunung Agung

Heidjrachman \& Husnan, S, (2002), Manajemen Personalia, Edisi Keempat,. Yogyakarta: BPFE.

Hidayat, Sucherli. (1986). Peningkatan Produktivitas Organisasi dan Pegawai Negeri Sipil: Kasus Indonesia, Jakarta:Prisma

Ivancevich, Konopaske Dan Matteson. 2006. Perilaku Manajemen dan Organisasi. alih bahasa Gina Gania. Jakarta : Erlangga.

Kemendikbud. (2018) Permendikbud No. 6 Tentang Penugasan Guru dan Kepala Sekolah .Jakarta: Kemendikbud

Likert. R. 1967. Organisasi Manusia. Jakarta: Erlangga.

Mc. Taggart, R dan Kemmis, S. 1990. The Action Research Planner. Melbourne. Deakin University.

Mills, Geoffrey. 2003. Action Research: A Guide for the Teacher Researcher. New Jersey: Prentice Hall.

Panitia Pelaksana Pendidikan dan Latihan Profesi Guru Rayon 10 Jawa Barat, 2009. Bahan Ajar Pendidikan dan Pelatihan Profesi Guru (PLPG)

Peraturan Pemerintah No. 30 Tahun 1980 Tentang Disiplin Pegawai Negeri Sipil.

Purwanto, Ngalim. (2006). Psikologi Pendidikan. Bandung: PT Remaja Rosdakarya.

Robbins, Stephen P. (1994). Teori Organisasi : Konsep, Struktur, Proses. Jakarta: Penerbit Arcan.

Rue dan Byars. (1995). Manajemen Pelayanan. Yogyakarta: Pustaka Pelajar.

Sagala, Syaiful, 2003, Konsep dan Makna Pembelajaran, Bandung: Alfabeta.

Sedarmayanti, M.Pd,. APU. (2009), Sumber Daya Manusia dan Produktivitas. Kerja. Bandung: Penerbit Mandar Maju.

Subekti, (1995), Aneka Perjanjian, Bandung: Intermasa.

Sutari Imam Barnadib. (1989) Pengantar Ilmu Pendidikan Sistimatis, Yogyakarta : FIIKIP.

Undang-undang Republik Indonesia No. 14 Tahun 2005. Tentang Guru dan Dosen

Veithzal, Rivai. 2005. Manajemen Sumber Daya Manusia Untuk Perusahaan. Jakarta : PT. Raja Grafindo Persada 